\title{
Educational Social Skills of parents of children with and without Intellectual Disability
}

\author{
Priscila Beniter. ${ }^{1}$ \\ Luz̨iane de Fátima Kirchner² \\ Giovan Willian Ribeiro ${ }^{3}$ \\ Daniely Ildegardes Brito Tatmatsu ${ }^{4}$ \\ ${ }^{1}$ Federal University of ABC, Santo André, São Paulo, Brasil \\ ${ }^{2}$ Dom Bosco Catholic University, Campo Grande, Mato Grosso do Sul, Brasil \\ ${ }^{3}$ Federal University of São Carlos, São Carlos, São Paulo, Brasil \\ ${ }^{4}$ Federal University of Ceará, Fortaleza, Ceará, Brasil
}

\begin{abstract}
Intellectual disability (ID) affects the functioning of adaptive behavior and social skills (SS). One way to increase SS can be through parental involvement, as long as parents have sufficient educational social skills (ESS) to favor SS teaching. The objective was to evaluate and compare the ESS of parents of children with and without ID, and to investigate correlations between ESS and age, schooling of the child/parent, and socioeconomic status. Participants included a total of 52 parents of children (26 in each group). Parents responded to the ESS Inventory. The analysis identified that the higher the educational level of the children with ID, the greater the general score and the ability of parents to talk and dialogue with them. The results identified statistically significant differences $(p<0.01)$ between the ESS repertoire of parents of children with and without ID, suggesting necessary interventions with parents of children with ID, especially for parents with a lower socioeconomic level.

Keywords: intellectual disability; educational social skills; parent-child relations
\end{abstract}

Habilidades Sociais Educativas de Pais de Crianças com e sem Deficiência Intelectual

\begin{abstract}
Resumo
A deficiência intelectual (DI) acomete o funcionamento do comportamento adaptativo e as Habilidades Sociais (HS). Uma forma de ampliar as HS pode ser por meio do envolvimento dos pais, desde que eles tenham Habilidades Sociais Educativas (HSE) suficientes para o ensino das HS. O objetivo foi avaliar e comparar as HSE de pais de crianças com e sem DI, e investigar correlações entre HSE e idade, escolaridade da criança/pais e nível socioeconômico. Participaram 52 pais de crianças (26 em cada grupo). Os pais responderam ao Inventário de HSE. A análise identificou quanto maior a escolaridade das crianças com DI, maior o escore geral e habilidade dos pais para conversar e dialogar com elas. Os resultados identificaram diferenças estatisticamente significativas $(p<0,01)$ entre HSE de pais de crianças com e sem DI, sugerindo a necessidade de intervenções com pais de crianças com DI, principalmente, para aqueles com menor nível socioeconômico.

Palavras-chave: deficiência intelectual, habilidades sociais educativas, relações pais-filho
\end{abstract}

Habilidades Sociales Educativas de padres de niños con y sin Discapacidad intelectual

\begin{abstract}
Resumen
La discapacidad intelectual (DI) afecta el funcionamiento del comportamiento adaptativo y las Habilidades Sociales (HS). Una forma de ampliar las HS puede ser a través de la participación de sus padres, siempre y cuando disponga de Habilidades Sociales Educativas (HSE) suficientes para favorecer la enseñanza de las HS. El objetivo fue evaluar y comparar el HSE de padres de niños con y sin DI, y evaluar correlaciones entre HSE y edad, escolaridad del niño/padre y nivel socioeconómico. Participaron 52 padres de niños (26 en cada grupo). El análisis identificó cuanto mayor la escolaridad de los niños con DI, mayor el puntaje general y habilidad de los padres para conversar y dialogar con ellas. Los padres respondieron el Inventario de HSE. Los resultados identificaron diferencias estadísticamente significativas $(\mathrm{p}<0,01)$ entre el repertorio de HSE de padres de niños con y sin DI, sugiriendo la necesidad de intervenciones con padres de niños con DI, principalmente para los padres con menor nivel socioeconómico, para favorecer el desarrollo socioemocional de estos niños.

Palabras clave: discapacidad intelectual; habilidades sociales educativas; relaciones padres-niños
\end{abstract}

Intellectual disability (ID) is characterized by limitations in intellectual functioning and adaptive behavior, expressed in conceptual, social, and practical skills, with onset before the age of 18 , according to the American Association on Intellectual and Developmental Disabilities - AAIDD (Almeida, 2004;
Freitas, \& Del Prette, 2010a; Luckasson, \& Reeve, 2001; Veltrone, \& Mendes, 2012). Difficulties in interpersonal skills are among the challenges presented by children, adolescents and/or adults with ID (Freitas, \& Del Prette, 2010a; b). It is a field that requires research and refers to the concept of Social Skills (SS), 
which are defined by Del Prette and Del Prette (2001) as the set of social behaviors that can contribute to the quality of interactions between people.

The main deficits in social behaviors in children with ID, according to Kleijin (2001), are related to assertiveness, expression of positive feelings, and coping skills. Freitas and Del Prette (2013) identified that there was greater impairment of SS in children with moderate ID compared to children with autism, Attention Deficit Hyperactivity Disorder (ADHD), and internalizing behavioral problems (e.g., anxiety, withdrawal and social isolation); these authors also found that the more severe the involvement of the ID, the greater the impairment of the SS repertoire.

There are ways to broaden the repertoire of SS in children with ID by means of a Social Skills Training - SST, mainly related to coping with social situations (Kleijin, 2001; Angélico \& Del Prette, 2011; Del Prette et al., 2012) in formal contexts, such as in school, and in informal contexts, such as at home and in parent-child interaction. Cardozo and Soares (2011) point out in a literature review that parents act as a model of behavior for their children and, in this sense, evaluating and promoting interpersonal skills of parents can be useful in the development and maintenance of their children's social repertoire. An earlier study evaluated the influence of parental SS and the involvement of parents and children with ID (Cardozo \& Soares, 2011), as well as the effect of parental SST on children's social and academic performance (Barros \& Del Prette, 2007). In both studies, parental SS were discussed in general contexts, rather than specifically in relation to the interaction with their children. Studies have highlighted the importance of parental social skills, especially those related to positive expression of feelings for parentchild involvement (Cardozo \& Soares, 2011) and the importance of parents acting as models for the development of their children's socially qualified behaviors, thus contributing for their social and academic performance (Barros \& Del Prette, 2007).

Given the importance of parental SS, there is a need to invest in assessments and interventions aimed at educational social skills, as they are intended to intentionally promote children's learning in social and academic contexts (Del Prette, \& Del Prette, 2001; 2008). Del Prette and Del Prette (2008) presented a System of Educational Social Skills with tasks for parents, teachers, and other educational agents committed to the promotion of the students' development. The authors described four molar categories, containing sub-items in each. The category 'Establishing potentially educational interactive contexts' involved the following target behaviors: arranging the physical environment, organizing materials, among others. The category 'Transmitting or exposing social skills content' covered items such as paraphrasing, presenting goals, etc. The category 'Setting limits and discipline' highlighted the following behaviors: describing / analyzing undesirable and desirable behaviors, negotiating rules, etc. The 'Positive monitoring' category involved such things as praise, encouragement, empathy, etc.

Cardozo and Soares (2011) suggest that such skills can help parents to show their children's their behavior, values and cultural norms, helping them to develop autonomy and their social inclusion. In addition, parent-child educational interactions include, for example, the ability of parents to instruct their children to express feelings, to present rules that are clear and coherent to their context and routine, to organize this routine, and to provide family-friendly models as well as models consistent with other values. Satisfactory parental performance in these interactions can occur when parents have a good ESS repertoire (Barros, \& Del Prette, 2007; Ferreira, \& Marturano, 2002; Santos, \& Graminha, 2006; Silva, Nunes, Betti, \& Rios, 2008).

However, research on the experience and family routine of parents of special education students has shown that they provide stimuli at home in the interaction between the dyad, but parents presented need for assistance, information, and financial support (Pavão, Gualda, (Santos, \& Christovam, 2018). Thus, it is understood that parents of children with ID can contribute to the promotion of their children's social behaviors and social and emotional development if they have different ESS in the interaction with their children (Barros, \& Del Prette, 2007; Benitez, \& Domeniconi, 2014; Ferreira, \& Marturano, 2002; Santos, \& Graminha, 2006; Silva, Nunes, Betti, \& Rios, 2008; Soares, Souza, \& Marinho, 2004). Nonetheless, there is no information yet regarding what are the resources and deficits of parents of children with ID in ESS and whether they are different from those of other parents. As a preliminary approach to these questions, this study aimed to compare the ESS repertoire of parents of children with and without ID, and to investigate the relationship of this repertoire with the participants' sociodemographic characteristics. If the differences are unfavorable for parents of children with ID, this may underlie the development of interventions aimed at empowering and instrumentalizing parents regarding 
ESS, as well as generating new research problems to verify the impact of such ESS on the social-emotional development of children with ID.

\section{Method}

\section{Ethical considerations}

This study was approved by the Research Ethics Committee of the Institution Federal University of São Carlos ( $\left.n^{\circ}: 42207\right)$ and complied with the norms for research with individuals.

\section{Participants}

Participants included a total of 19 mothers and seven fathers of children with a medical diagnosis of ID, and to contrast the data we also analyzed 21 mothers and five fathers of children without any diagnosis. The criteria established for the selection of children with ID involved three aspects: 1) medical diagnosis of ID attached to the school record; 2) presence of cognitive impairment, according to the teacher's report; and 3) WISC-III score equal to or less than 69. And for the other group: 1) no medical diagnosis of ID, as informed in the school record; and 2) absence of cognitive impairment, according to the teacher's report. For parents in both groups, another criterion was their availability to respond to the instruments established in the present study.

\section{Instruments}

Wechsler Intelligence Scale for Children (WISC-III Wescheler, 1997). An instrument composed of subtests that evaluate the individual's global intelligence by means of the total, verbal, and execution intelligence coefficients. The purpose of the application in the present study was to characterize the intellectual repertoire of each student who had a diagnosis of ID. This instrument was used exclusively to obtain one of the inclusion criteria of children with ID, whose parents participated in the study.

Inventory of Educational Social Skills - Parents (IHSEParents, Del Prette, \& Del Prette, 2013). Self-report inventory consisting of 60 items that describe social behaviors of parents presented in relation to their

Table 1.

Descriptive data of the group with DI and the group without ID

\begin{tabular}{|c|c|c|}
\hline & Group with ID & Group without ID \\
\hline Parents' age (median) & 38.9 years $($ s.d. $=7.46)$ & 36.5 years $($ s.d. $=6.41)$ \\
\hline Parent's level of education (frequency) & $\begin{array}{l}\text { Elementary School }=5 \\
\quad \text { High School }=6 \\
\text { Higher Education }=15\end{array}$ & $\begin{array}{c}\text { Element. School = } 1 \\
\text { High School = } 11 \\
\text { Higher Education }=14\end{array}$ \\
\hline $\begin{array}{l}\text { Children's age } \\
\text { (median) }\end{array}$ & 8.56 years $($ s.d. $=3.68)$ & 7.73 years $($ s.d. $=3.8)$ \\
\hline Children's sex (percentage) & $\begin{array}{l}\text { 38.5\% Female } \\
61.5 \% \text { Male }\end{array}$ & $\begin{array}{l}38.5 \% \text { Female } \\
61.5 \% \text { Male }\end{array}$ \\
\hline $\begin{array}{l}\text { Children's level of education } \\
\text { (frequency) }\end{array}$ & $\begin{array}{c}\text { Pre-school }=8 \\
\text { Element. School = } 18\end{array}$ & $\begin{array}{c}\text { Pre-school }=7 \\
\text { Element. School }=14 \\
\text { High School }=5\end{array}$ \\
\hline Socio-economical level (frequency) & $\begin{array}{l}\mathrm{D}=1 \\
\mathrm{C} 2=7 \\
\mathrm{C} 1=3 \\
\mathrm{~B} 2=6 \\
\mathrm{~B} 1=7 \\
\mathrm{~A} 2=2\end{array}$ & $\begin{array}{l}\mathrm{C} 2=3 \\
\mathrm{C} 1=7 \\
\mathrm{~B} 2=9 \\
\mathrm{~B} 1=5 \\
\mathrm{~A} 2=2\end{array}$ \\
\hline
\end{tabular}


children. Items are arranged on a Likert-like scale, and response options include Never or Almost Never, Rarely, Often, Almost Always, and Always. The scale items were elaborated from the Educational Social Skills Category System, proposed by Del Prette and Del Prette (2008), but reworked and expanded according to the literature and other studies previously conducted by the authors.

The instrument generates a total score $(\alpha=$ $0.957)$ and five factorial scores produced by Principal Axis Factoring, with PROMAX rotation: F1 = Setting limits, correcting, controlling $(\alpha=0.936)$; F2 = Showing affection and attention ( $\alpha=0.883)$; F3 = Talking/ Dialoguing $(\alpha=0.851)$; F4 $=$ Inducing discipline $(\alpha=$ $0.791) ; \mathrm{F} 5=$ Organizing educational conditions $(\alpha=$ 0.748). An analysis of the discriminative potential of the items revealed that all showed positive discrimination in the difference between the groups with the highest and lowest scores that indicated the maximum points of the scale: in half of the items the difference was equal to or greater than $50 \%$. The correlation between item and total score was also positive and significant for all items, ranging from 0.372 to 0.692 . Precision (test-retest) and intervention sensitivity data are not yet available (Del Prette, \& Del Prette, 2013).

Criterion of Brazil Economic Classification (CCEB, Brazilian Association of Research Companies (ABEP), 2013): instrument used for socioeconomic classification, whose score is based on the number of durable consumer items and the head of household's schooling. The instrument identifies seven classes of purchasing power, presented in descending order: A1, A2, B1, B2, $\mathrm{C}, \mathrm{D}$, and $\mathrm{E}$.

\section{Data collection procedure}

The instruments were administered in public schools in a small town in the countryside of the state of São Paulo, where the participants' children studied. Parents of children with and without ID were recruited from regular public schools, as indicated by the Municipal Department of Education.

The sample was selected by convenience. At school meetings, parents were informed of the research procedures and invited to participate. Those who agreed to participate signed the Informed Consent Form and subsequently responded to the IHSE-Parents (Del Prette, \& Del Prette, 2013) and the CCEB (Brazilian Association of Research Companies, 2013) instruments.

After the parents completed the instruments, the school records were checked for the presence or absence of a medical diagnosis of ID, and the teachers were consulted to obtain information about the child's cognitive impairment. Once the information was confirmed, children identified with ID were submitted to WISC-III evaluation (Wescheler, 1997), and those who reached a score equal to or lower than 69 were included in the study.

\section{Data analysis}

Participant responses were recorded in IBM SPSS Statistics (version 21) spreadsheets, in which statistical tests were also performed. The Kolmogorov-Smirnov test indicated that the sample scores did not present normal distribution for any of the factors $(p<0.05)$ and, therefore, statistical comparisons between groups were performed using the non-parametric Mann Whitney test $(p<0.05)$ for independent samples. The relationship between the variables was conducted by Spearman's correlation coefficient $(\mathrm{p}<0.05)$. No descriptive statistical analysis was performed, since for the purposes of the present study, inferential analyzes were performed, and descriptive data presented in Table 2.

The homogeneity of the samples was attested by comparing the sociodemographic data of each group. No differences were found between the groups with and without ID when the Mann Whitney test was applied to compare the age of the children $(\mathrm{U}=376$; $\mathrm{p}=0.33)$ and the age of the parents $(\mathrm{U}=404 ; \mathrm{p}=$ $0.22)$. Similarly, no differences were found when comparing parental sex $(\chi 2=0.43 ; \mathrm{p}=0.51)$ and parental schooling $\left(\chi^{2}=0.07 ; \mathrm{p}=0.78\right)$ using the Chi-square test. The median test was used to compare children's schooling $\left(\chi^{2}=5.12 ; \mathrm{p}=0.73\right)$ and the parents' socioeconomic level $(\chi 2=0.08 ; p=1)$, and indicated that there was no significant difference between groups regarding these aspects.

\section{Results}

The descriptive data (median, minimum and maximum) of the scores, by factor and by group, are shown in Table 2, together with the inferential values (from $\mathrm{U}$ and $p$ provided by the Mann Whitney test) of the groups of parents of children with and without ID.

Comparison between the general ESS scores of the two groups showed a significant difference $(\mathrm{U}=$ $81.5 ; p<0.01)$, and parents of children with ID presented lower scores than parents of children without ID. Similarly, significant differences were found between the groups in the five IHSE-Del-Prette factors: Factor 
1 (Set limits, correct, control); Factor 2 (Show affection and attention); Factor 3 (Chat / Dialogue); Factor 4 (Induce discipline); and F5 (Organize educational conditions). Correlation data between sociodemographic factors and variables for the ID Group are presented in Table 3.
The Spearman's test revealed significant positive correlations between the education of children with ID and their parents' score in Factor $3(\varrho=0.41 ; \mathrm{p}<0.05)$ and in the General Score $(\varrho=0.46 ; p<0.05)$. For this same group of children, positive correlations were observed between socioeconomic status, Factors 1 ( $\varrho=$

Table 2.

Descriptive and inferential data of parental general and factorial score

\begin{tabular}{|c|c|c|c|c|c|c|}
\hline Factors & Groups & Median & Minimum & Maximum & $U$ & $p$ \\
\hline \multirow[t]{2}{*}{ General Score } & With ID & 150.0 & 67.0 & 206.0 & 081.5 & $<0.01$ \\
\hline & Without ID & 193.4 & 148.0 & 238.85 & & \\
\hline \multirow[t]{2}{*}{ F1 - Set limits, correct, control } & With ID & 67.0 & 20.0 & 103.0 & 120.0 & $<0.01$ \\
\hline & Without ID & 84.5 & 61.0 & 104.0 & & \\
\hline \multirow{2}{*}{$\begin{array}{l}\text { F2- Show affection and } \\
\text { attention }\end{array}$} & With ID & 43.0 & 19.0 & 48.0 & 194.0 & $<0.01$ \\
\hline & Without ID & 46.0 & 38.0 & 48.0 & & \\
\hline \multirow{2}{*}{$\begin{array}{l}\text { F3 - Talk / } \\
\text { dialogue }\end{array}$} & With ID & 16.5 & 3.0 & 35.0 & 067.5 & $<0.01$ \\
\hline & Without ID & 31.5 & 20.0 & 40.0 & & \\
\hline \multirow[t]{2}{*}{ F4 - Induce discipline } & With ID & 09.0 & 0.0 & 21.0 & 113.5 & $<0.01$ \\
\hline & Without ID & 16.0 & 10.0 & 24.0 & & \\
\hline \multirow{2}{*}{$\begin{array}{l}\text { F5 - Organize educational } \\
\text { conditions }\end{array}$} & With ID & 11.5 & 2.0 & 21.0 & 141.0 & $<0.01$ \\
\hline & Without ID & 17.0 & 9.0 & 24.0 & & \\
\hline
\end{tabular}

Table 3.

Correlations between scores of parents of children / adolescents with ID in the five factors and sociodemographic variables

\begin{tabular}{lccccc}
\multicolumn{1}{c}{ Scores } & Child's age & $\begin{array}{c}\text { Child's } \\
\text { schooling }\end{array}$ & Parental age & $\begin{array}{c}\text { Parental } \\
\text { schooling }\end{array}$ & Parental SEL \\
\hline General Score & 0.09 & $0.41^{*}$ & -0.16 & -0.32 & $0.47^{*}$ \\
F1 - Set limits, correct, control & 0.08 & 0.39 & -0.25 & -0.30 & $0.49^{*}$ \\
F2- Show affection and attention & 0.11 & 0.30 & -0.03 & -0.12 & 0.14 \\
F3 - Talk/ dialogue & 0.12 & $0.46^{*}$ & -0.03 & -0.34 & $0.39^{*}$ \\
F4 - Induce discipline & -0.006 & 0.31 & -0.36 & -0.36 & $0.58^{*}$ \\
F5 - Organize educational conditions & -0.34 & -0.09 & $0-.13$ & -0.22 & 0.30 \\
\hline
\end{tabular}

$* p<0.05$ 
$0.49 ; \mathrm{p}<0,05), 3(\varrho=0.39 ; \mathrm{p}<0.05)$, and $4(\varrho=0.58$; $p<0.01)$, and the General Score $(\varrho=0.47 ; p<0.01)$.

Regarding the group of parents of children without ID (Table 4), Factor 3 correlated positively with socioeconomic status $(\varrho=0.44 ; \mathrm{p}<0.05)$, age $(\varrho=$ $0.51 ; p<0.01)$, and children's schooling $(\varrho=0.60 ; p$ $<0.01$ ), and negatively with parental schooling ( $\varrho=$ $-0,47 ; p<0,01)$. Also, Factor 4 scores presented positive correlation with socioeconomic status $(\varrho=0.53$; $p<0.01)$ and negative with parental schooling ( $\varrho=$ $-0.41 ; p<0.05)$.

\section{Discussion}

The present study aimed to evaluate and compare the ESS repertoire of parents of children with and without ID, in order to verify the need for the development and improvement of future interventions aimed at training and instrumentalizing skilled behaviors for parents. Another objective outlined for the study involved investigating the relationship of this repertoire with the sociodemographic characteristics of the participants.

According to the data analyzed, the parents of children without ID had a higher repertoire of ESS, compared to the parents of children with ID, in all subscales of the ESS, besides the General Score, which confirms the hypothesis initially raised. Also, when comparing the parents of children with ID, with higher and lower socioeconomic status, those with lower socioeconomic status presented a poorer repertoire of SS, compared to those with a higher level. The restricted repertoire of SS of children with ID, given in the very definition of this diagnostic picture (Almeida, 2004; Freitas, \& Del Prette, 2010b; Luckasson, \& Reeve, 2001; Veltrone, \& Mendes, 2012, Angelico \& Del Prette, 2011; Kleijin, 2001), would already be sufficient justification to promote and expand ESS in informal contexts, such as parent-child interaction.

In the group of parents of children without ID, the analysis also indicated that the higher the socioeconomic level and the child's age and education, the greater the ability of parents to talk and dialogue (F3). These data indicate that regardless of the presence of a diagnosis of ID, parents may provide better conditions and opportunities for dialogue with older and / or more educated children. Relationships between children with ID and their parents (Cardozo \& Soares, 2011), as well as in children without ID, seem to occur similarly, regardless of diagnosis, in relation to the age of their children, meaning that parents of young children tend to provide more instruction and less decision-making autonomy, which may indicate less time for dialogue compared to the interaction of parents with older children.

The findings of this study regarding the impairment of ESS in parents of children with ID further

Table 4.

Correlation between scores of parents of children / adolescents without ID in the five sociodemographic factors and variables. Scores

\begin{tabular}{lccccc}
\hline Scores & Child's age & $\begin{array}{c}\text { Child's } \\
\text { schooling }\end{array}$ & Parental age & $\begin{array}{c}\text { Parental } \\
\text { schooling }\end{array}$ & Parental SEL \\
\hline General Score & 0.07 & 0.14 & 0.31 & -0.27 & 0.34 \\
F1 - Set limits, correct, control & 0.04 & 0.05 & 0.14 & -0.21 & 0.27 \\
F2- Show affection and attention & -0.38 & -0.32 & -0.08 & 0.13 & -0.009 \\
F3 - Talk/dialogue & $0.51^{* *}$ & $0.60^{* *}$ & 0.05 & $-0.47^{*}$ & $0.44^{*}$ \\
F4 - Induce discipline & 0.12 & 0.26 & -0.11 & $-0.41^{*}$ & $0.53^{* *}$ \\
F5 - Organize educational conditions & -0.18 & -0.12 & 0.01 & -0.12 & 0.14 \\
\hline
\end{tabular}

$* p<0.05$

${ }^{*} p<<0.01$ 
highlight the need for interventions with this scope, directed at parents. It is possible that parents of children with ID evaluate themselves as less able to promote educational strategies and situations for their children with ID, perhaps due to the difficulties arising from the ID itself, as well as from the social and cultural context in which they are inserted.

According to Molina and Del Prette (2006), to analyze the repertoire of SS of both parents and children, it is essential to understand the social and cultural context, due to the influence that such context has to favor or hinder the adaptive functioning of each individual, especially regarding the independence, responsibility and quality of relationships. This impairment in relation to the repertoire, identified by parents, may be due to the absence of repertoire (acquisition deficit) or low occurrence of these repertoires in interaction with their children (performance deficit). Future research may focus on investigating more specifically such relationship between repertoire acquisition or number of occurrence of these behaviors in the interaction between parents and children with ID.

In the group of parents of children with ID, the socioeconomic level was the variable that indicated a positive correlation with the higher number of factors of the IHSE instrument (Del Prette \& Del Prette, 2013), that is, those parents who presented better socioeconomic conditions also presented greater ability to set limits, correct, control (F1), talk / dialogue (F3) and induce discipline (F4), as well as better repertoire of educational social skills in general. However, the same type of correlation was not identified in the group of parents of children without ID.

The data suggest that parents of children with ID who are more resourceful, whether financial, or regarding access to information, are more engaged in seeking guidance, courses and activities that enable them to learn how to cope with their child's difficulties, which may in part favor the development of a positive social interaction between parents and children (Del Prette \& Del Prette, 2008). Courses and guidance in this area are still very restricted to a specific group of the Brazilian population and, when they are publicly accessible, they still have a more directed character to certain studies, instead of being applied in a public management model. These data highlights the importance of providing information to parents, as well as support, which dialogues with the findings identified in the study by Pavão et al., (2018). One way to deal with this situation is to propose training for parents to develop ESS, for example. The study by Benitez and Domeniconi (2014) proposed training for parents and teachers of students with ID and Autistic Spectrum Disorder, having as one of the stages the discussion about information on ESS.

The analysis also pointed out that the higher the educational level of children with ID, the higher the overall score and the ability of parents to talk and dialogue with them. This may mean that the educational variable (represented in social terms) can contribute as a moderating factor for parents' ESS in interaction with their children. Therefore, the data suggest that the higher the child's schooling, the greater the parents' perception that the child can communicate, express opinions, make decisions, and the more time and occasion parents can give to dialogue with them.

Another data analyzed was that the lower the parental schooling, the better the ability to talk and induce discipline. Except under the conditions of having a child with ID, where engagement in seeking improvements to cope with the child's difficulties may be a positive factor in building a socially skilled repertoire in parents, the education of parents of children without ID does not seem to contribute to the development of this skill for parents. Perhaps because more educated parents point to other situations as a priority, in relation to their children's development. In the presence of a diagnosis, parents seem to seek training to deal with the difficulties of the child with ID, which may not occur when the child shows a child development without disability or disorder. Parents of children with ID, who have a lower socioeconomic status, are perhaps the focus of greatest concern, as they have more difficulty in relation to ESS.

Although it is not possible to state that the higher socioeconomic status of parents of children with ID is responsible for promoting, to a greater degree, parental ESS, future studies can verify whether sociodemographic variables, both of parents and children, are relevant to understand the ESS repertoire of parents of children with ID. In addition, considering that the greater the impairment of the ID, the greater the impairment of SS in these children (Freitas \& Del Prette, 2013), it is possible to investigate how these variables impact the quality of children's interaction with their parents and, therefore, the ESS repertoire of the latter.

Finally, understanding ID as a multidetermined biological, social, and psychological condition, although the biological marker has not been identified, in terms of diagnostic evaluation, it is possible to discuss issues 
related to the intergenerationality of SS present in the interactions of parents and children with and without ID (Comodo, Del Prette \& Del Prette, 2017; Luckasson, \& Reeve, 2001; Veltrone, \& Mendes, 2012). Considering the literature that points out the repertoire of SS of children with ID and, in this study (Table 2), the restricted repertoire of ESS of their parents, the issue of intergenerationality may be involved, at least in terms of social skills, making it difficult to expand their children's social interactions repertoire.

\section{Conclusions}

The impairment of ESS in parents of children with ID can negatively affect the establishment of the family as a promoter of contingencies that support their children's acquisition of new behaviors. This scenario tends to be aggravated by a context of socioeconomic constraint.

Considering the situation of parents of children with ID, their repertoire of ESS and the importance of developing more stimuli with these children, the data from this study suggest the need and urgency of ESS programs for their parents, especially in relation to setting limits, correcting, controlling, as well as showing affection and attention, talking / dialoguing, inducing discipline, and organizing educational conditions, as identified in this study, and regarding what the literature points about behavior of parents of children with ID. Such programs, if implemented, may target both the socio-emotional development of children with ID and academic learning. ESS programs aimed at other target populations have shown positive effects for both educators and children (Rocha, Del Prette \& Del Prette, 2013; Rosin-Pinola, Marturano, Elias \& Del Prette, 2017).

One of the limitations of the present study is the use of a convenience sample, which limits the generalization of the data. In addition, the use of participants' self-report instruments should be carefully evaluated, as the social desirability factor cannot be ruled out. Future studies are suggested to link ID levels (mild, moderate and severe) with the SS repertoire, as well as with their parents' ESS, in order to verify whether the parents' ESS vary in relation to their children's level of ID.

\section{References}

Almeida, M. A. (2004). Apresentação e análise das definições de deficiência mental propostas pela
AAMR - Associação Americana de Retardo Mental de 1908 e 2002. Revista de Educaşão (Campinas), 6, 33-48. Recuperado de: http://periodicos.puccampinas.edu.br/seer/index.php/reveducacao/ article/view/284

Angélico, A. P., \& Del Prette, A. (2011). Avaliação do repertório de habilidades sociais de adolescentes com síndrome de Down. Psicologia: Reflexão e Crítica, 24 (2), 207-217. doi: 10.1590/ S0102-79722011000200001.

Barros, S. K. S. N., \& Del Prette, A. (2007). Um treinamento de habilidades sociais para pais pode beneficiar os filhos na escola? Revista da Sociedade de Psicologia do Triângulo Mineiro, 11(1), 107-123. doi: 10.1590/S0102-79722006000300009.

Benitez, P., \& Domeniconi, C. (2014). Capacitação de agentes educacionais: proposta de desenvolvimento de estratégias inclusivas. Revista Brasileira de Educação Especial, 30(3), 371-386. doi: 10.1590/ S1413-65382014000300005.

Cardozo, A., \& Soares, A. B. (2011). Habilidades sociais e o envolvimento de pais e filhos com deficiência intelectual. Psicologia: Ciência e Profissão, 31(1), 110119. doi: 10.1590/S1414-98932011000100010.

Comodo, C. N., Del Prette, A., \& Del Prette, Z. A. P. (2017). Intergeracionalidade das habilidades sociais entre pais e filhos adolescentes. Psicologia: teoria e pesquisa, 33(1), 1-9. doi: 10.1590/0102.3772e33311.

Del Prette, A., \& Del Prette, Z. A. P. (2001). Psicologia das relações interpessoais: Vivências para o trabalho em grupo. Petrópolis: Vozes.

Del Prette, Z. A. P., \& Del Prette, A. (2008). Um sistema de categorias de habilidades sociais educativas. Paidéia, 18(41), 517-530. Ribeirão Preto. doi: 10.1590/ S0103-863X2008000300008.

Del Prette, Z. A. P. \& Del Prette, A. (2013). Inventário de habilidades Sociais Educativas - versão Pais (IHSE-Pais): Dados psicométricos preliminares. Relatório não publicado disponível com os autores.

Del Prette, Z. A. P., Del Prette, A., Gresham, F. M., \& Vance, M. J. (2012). Role of social performance in predicting learning problems: Prediction of risk using logistic regression analysis. School Psychology International Journal 33(6), 615-630. doi: 10.1177/0020715211430373.

Psico-USF, Bragança Paulista, v. 25, n. 3, p. 415-424, jul./set. 2020 
Ferreira, M. C. T., \& Marturano, E. M. (2002). Ambiente familiar e os problemas do comportamento apresentado por crianças com baixo desempenho escolar. Psicologia: Reflexão e Crítica, 15(1), 33-44. doi: 10.1590/S0102-79722002000100005.

Freitas, L. C., \& Del Prette, Z. A. P. (2010a). Comparando autoavaliação e avaliação de professores sobre as habilidades sociais de crianças com deficiência mental. Interpersona, 4(2), 183-193. doi: 10.5964/ ljpr.v412.48.

Freitas, L. C., \& Del Prette, Z. A. P. (2010b). Validade de construto do Sistema de Avaliação de Habilidades Sociais para crianças brasileiras com deficiência intelectual. Interamerican Journal of Psychology, 44, 312320. doi: 10.1590/S0102-79722010000300003.

Freitas, L. C. de \& Del Prette, Z. A. P. (2013). Habilidades sociais de crianças com diferentes necessidades educacionais especiais: Avaliação e implicações para intervenção. Avances en Psicologia Latinoamericana, 31(2), 364-382. Recuperado de: https://revistas.urosario.edu.co/index.php/apl/ article/viewFile/2144/2102

Kleijn, M. V. L. B. (2001). Avaliação das condições escolares para o desenvolvimento de habilidades sociais em alunos com retardo mental. Dissertação de Mestrado não-publicada, Programa de Pós-Graduação em Educação Especial, Universidade Federal de São Carlos, SP. Recuperado de: http://betara.ufscar.br:8080/ pesquisa/rihs/pesquisas/armazenagem/pdf/ resumos-dissertacao/a-avaliacao-das-condicoesescolares-para-o-desenvolvimento-de-habilidadessociais-em-criancas-com-retardo-mental

Luckasson, R., \& Reeve, A. (2001). Naming, defining and classifying in mental retardation. Mental retardation, 39, 47-52. doi: 10.1352/0047-6765(2001)039.

Molina, R. C. M., \& Del Prette, Z. A. P. (2006). Funcionalidade da relação entre habilidades sociais e dificuldades de aprendizagem. Psico-USF, 11(1), 53-63. Recuperado de: http://www.scielo.br/pdf/ pusf/v11n1/v11n1a07
Pavão, M. R., Gualda, D. S., Cia, F., Santos, L. S., \& Christovam, A. M. C. (2018). Rotina e necessidades de apoio: relato de familiares de crianças de zero a dois anos Público Alvo da Educação Especial. Revista Educação Especial, 31, 447-462. doi: 10.5902/1984686X

Rocha, M.M., Del Prette, Z.A.P. \& Del Prette, A. (2013). Avaliação de um programa de habilidades sociais educativas para mães de crianças com TDAH. Acta Comportamentalia, 21(3), 359-375. Recuperado de: http://pepsic.bvsalud.org/pdf/actac/v21n3/a06. pdf

Rosin-Pinola, A.R., Marturano, E.M., Elias, L.C.S. \& Del Prette, Z.A.P. (2017). Ensinando habilidades sociais educativas para professores no contexto da inclusão escolar. Revista de Educação Especial, 30(59), 737-750. doi: 10.5902/1984686x28430

Santos, P. L., \& Graminha, S. S. V. (2006). Problemas emocionais e comportamentais associados ao baixo rendimento acadêmico. Estudos de Psicologia, 11(1), 101-109. doi: 10.1590/ S1413-294X2006000100012.

Silva, N. C. B., Nunes, C. C., Betti, M. C. M., \& Rios, K. S. A. (2008). Variáveis da família e seu impacto sobre o desenvolvimento infantil. Temas em Psicologia, 16(2), 215-229. Recuperado de: http://pepsic.bvsalud.org/scielo.php?script=sci_ arttext\&pid=S1413-389X2008000200006

Soares, M. R. Z., Souza, S. R., \& Marinho, M. L. (2004). Envolvimento dos pais: Incentivo à habilidade de estudos em crianças. Estudos de Psicologia (Campinas), 21(3), 253-260. doi: 10.1590/ S0103-166X2004000300009.

Veltrone, A. A., \& Mendes, E. G. (2012). Impacto da mudança de nomenclatura de deficiência mental para deficiência intelectual. Educação em Perspectiva, 3(2), 448-450. doi: 10.22294/eduper/ppge/ufv. v3i2

Recebido em: 22/06/2018

Reformulado em: 12/04/2019

Aprovado em: 22/07/2019 
About the authors:

Priscila Benitez is PhD in Psychology from Federal University of São Carlos - UFSCar. She is currently Researcher in National Institute of Science and Technology about Behavior, Cognition and Teaching. Adjunct Professor of Federal University of ABC.

ORCID: https://orcid.org/0000-0003-3501-7606

E-mail: priscila.benitez@ufabc.edu.br

Luziane De Fátima Kirchner is PhD in Psychology from Federal University of São Carlos - UFSCar. She is currently Professor at the Dom Bosco Catholic University - UCDB.

ORCID: https://orcid.org/0000-0002-3579-1768

E-mail: luzianek@yahoo.com.br

Giovan Willian Ribeiro holds a bachelor's degree and a master's degree in psychology from the Federal University of São Carlos. He is currently a doctoral student in the Graduate Program in Psychology at the Federal University of São Carlos and has a doctoral scholarship from the São Paulo Research Support Foundation (FAPESP, process \# 2017 // 25786-8).

ORCID: https://orcid.org/0000-0003-0631-9381

E-mail: giovanwillian@gmail.com

Daniely Ildegardes Brito Tatmatsu - Adjunct Professor of Federal University of Ceará. Coordinator of the Experimental Behavior Analysis Laboratory (LACCE).

ORCID: https://orcid.org/0000-0003-2279-6997.

E-mail: danielybrito@gmail.com

Contact:

Av. dos Estados, 5001, Bangú

Santo André-SP, Brasil

CEP: 09210-580 